\title{
Integrating ICT into second language education in a vocational high school
}

\author{
S. S.C. Young \\ National Tsing Hua University, Taiwan,
}

\begin{abstract}
This study investigated the potential impacts of integrating the Internet into an English as a second language class in a vocational senior high school in Taiwan. Twenty-nine students and a young male English teacher were involved. It was found that the students overall had a positive perception toward using Internet tools. This study indicated that the integration of information communication technology on the Internet with English facilitated the creation of a virtual environment that transformed learning from a traditional passive experience to one of discovery, exploration, and excitement in a less stressful setting. The study revealed that a computer-mediated communication environment could lower students' psychological barriers to enable them to express their opinions freely and to communicate actively on the Internet and that it could also enhance their critical thinking, problem-solving and communication skills through online activities or class homepage construction. An individual case study further revealed that a task-oriented English tutoring strategy in association with email communication could motivate the student's writing competence but the student's language proficiency and grammatical accuracy did not improve. Finally, based on the findings, recommendations for future studies are made.
\end{abstract}

Keywords: Case study; Communication; Discourse analysis; Email; English; ESL; ICT-use; Interview; Questionnaire; School; Secondary

\section{Introduction}

The popularity of information communication technology over the past decade has brought about the innovative use of the Internet in second language learning and teaching, particularly in the area of English as a second language (ESL) (Liao, 1999; Liou, 2000; Shetzer \& Warschauer, 2000; Warschauer, 2000). Web tools such as email, World-wide web, Chat room and MOO have been integrated in ESL learning and teaching materials (Yang, 2001; Chien \& Liou, 2002). Obviously, information communication technology (ICT) has changed the language learning and literacy acquisition environment as well as the dynamics of the language learning settings. The paradigm shift of computer-assisted language learning (CALL) from the cognitive approach to the socio-cognitive paradigm and the use of computer-

Accepted 21 December 2002

Correspondence: Shelley Shwu-Ching Young, Center for General Education and Institute of Information Systems and Applications, National Tsing Hua University, Hsin-Chu, Taiwan Email: scy@mx.nthu.edu.tw 
mediated communication, make language learning settings more socially interactive, collaborative, communicative and student-centred (Kern, \& Warschauer, 2000).

\section{Literature review}

Since the early 1960s, affective/psychological factors have been identified as having an influence on second language learning (Pike, 1967; Gardner \& Lambert, 1972; Heyde, 1979; Watkins et al., 1991). Inhibition, for instance, has long been regarded as a factor that hinders student second language acquisition (Guiora et al., 1972; Guiora et al., 1980). With an increase in age, the rise of the ego boundary becomes an influential factor in lowering student second language performance. Being afraid of poor performance in front of other people, students tend to be silent in class. This is particularly noticeable in Asian English as second language learning classes. In the 1990s related studies indicated that students who used to be shy in face-to-face discussion and who were considered low achievers in language learning became more active participants in computer-assisted classroom discussion (Beauvois, 1992; 1995; Kelm, 1992). Students with thin ego boundaries might exhibit better performance in language learning situations (Ehrman, 1993).

The Internet has the potential to provide a new learning environment that has rich digital textual, graphic, audio, video and other interactive features for the language learning approach as well as for culture (Muehleisen, 1997). The Internet is considered a key-factor in enhancing the learner's motivation for both language learning and linguistic proficiency (Lee, 2000). In recent years, language teachers have been exploring ways in which ICT can be employed to make language learning more effective and motivating for students (Vallance, 1998; Donaldson \& Kotter, 1999; Yang, 2001; Chien \& Liou, 2002). According to Muehleisen (1997), reasons for using the Internet in the English classroom are as follows:

- learning to use computers provides a strong intrinsic motivation for learning

English;

- the Internet places English in an international context;

- Internet projects are interactive;

- facilities for using the Internet are often readily available.

Research shows that by using network computers, students can be empowered by the capacities of the technology and become better problem solvers and communicators (Belisle, 1996; Al-Kahtani, 1999). Computer-mediated communication is different from face-to-face conversation in several ways. In an asynchronous communication mode, for example, there is often a time lag between the initial posting of a message and the responses it generates. Interactivity can be delayed at the convenience and readiness of the respondents. In addition, communication messages are scripts that are archived and saved. The automatically recorded digital messages allow participants to randomly refer back to previous postings within a discussion thread in ways that faceto-face experiences never afford. With the integration of ICT in language learning, new kinds of activities, such as electronic communication via email or chatrooms, have also been developed to help students. Different modes include synchronous and asynchronous interactive email, webchat, MOOs, IRC-multimedia activities, webbased reading, and task-oriented activities. Each mode fosters a different kind of linguistic competence and calls for various skills (Negretti, 1999; Liou, 2000). Computer-mediated communication, for example, provides an interactive learning environment to promote communicative language learning and the opportunity for 
authentic use of the learned language; encourages collaborative writing for enhancing English as the second language writing development through increasing engagement, confidence and responsibility; fosters student empowerment to increase students' control of the content and process of their own learning; and ultimately promotes student motivation and interest in the functional use of the learned language and provides students with a less threatening means to communicate (Chun, 1994; Beauvois, 1995; Skinner \& Austin, 1999). However, in a study using synchronous and asynchronous communication modes in a web-based English learning environment, it was found that learners had more difficulties with synchronous communication than with asynchronous communication due to both their limited English level and their typing speed (Chien \& Liou, 2002).

ESL teachers have to consider how to teach language literacy and technological skills so that learners can make effective use of ICT. When teachers develop and implement an electronic literacy approach, they must address a number of questions:

- How should ESL teachers make the best use of new online opportunities to maximise language study and practice while also helping students develop computer-based communication and literacy skills?

- What strategies for communicating and networking should students be taught?

- What goals should language teacher aim for and what kinds of online projects could students carry out to accomplish those goals?

- Which are the most crucial electronic resources and tools that teachers should learn about so that they can teach them to their students?

- How can teachers encourage students to become autonomous learners who can continue to learn how to communicate, conduct research and present their ideas effectively using information communication technology beyond the confines of the class or semester? (cited in Shetzer \& Warschauer, 2000, 171-172)

Taiwan is also trying to keep pace with the advances of ICT. Some young English teachers, along with school administrators and government agencies, have invested their time and efforts in the hope of introducing new teaching methods to improve English education (Liou, 2000; Yang, 2001; Chien \& Liou, 2002). The current study investigated and documented how an English teacher endeavoured to integrate information communication technology in his English class. It is hoped that that the study will provide insights toward a better understanding of vocational high school students' use of the Internet in a specific English learning setting in Taiwan.

\section{Purpose of the study}

The purpose of this study was to explore the use of the Internet in vocational highschool English learning environments in a specific socio-cultural context in Taiwan, including in the physical world and in cyberspace. The results of the in-depth study aim to shed light on the combinations of English language and ICT that can both enhance vocational high-school students' technological competence as well as facilitate English language acquisition and applications in an authentic situation.

\section{Research questions}

Specific questions explored in the study include the following:

- Can students learn the functions of the Internet via the English language and significantly improve their English e-talk on the Internet?

- What are the benefits or difficulties with the use of Information Communication 
Technology in the teaching of English as a Second Language?

- What are the perceptions of both teacher and students regarding the use of the Internet in the class?

- What are the issues and challenges that arise in the integration of the Internet in English learning contexts?

- Can students feel comfortable communicating in English on the Internet? Can the design of the Internet and English class improve their language proficiency and grammatical usage?

The setting for the study

The research study was conducted at a vocational high school in the northern part of Hsin-chu city in Taiwan. The course was named 'Internet and English'; its major objective was to help vocational high school students learn English in a natural setting with the assistance of ICT.

This course used various methods to facilitate students' Internet usage by way of English writing. A two-hour on-line lecture plus a computer session was held on Tuesdays in a computer lab where 30 Personal Computers were set-up and networked. In the lab the teacher lectured on some introductory aspects of the Internet and its functions and at the same time demonstrated its uses and gave students opportunities for practice using English and exploring the Internet. In addition to the weekly lecture and computer session, the after-class activities and assigned tasks were required of each student. To carry out the after-class projects and assignments, the students therefore needed to connect to the Internet and search for the required materials in response to the teacher's weekly questions and, meanwhile, they were required to use English to communicate with the teachers as well as with the other classmates.

Although ICT facilities and support were limited in the vocational school studied, the English teacher wanted to overcome the barrier by the inclusion of some outside-campus network resources in his class. For example, without any web space provided by the high school, the teacher applied for a free web space from a free Internet Service Provider (ISP) and set up a class homepage with the assistance of a designated student. On the class webpage, a course syllabus, updated announcements, handouts, profiles of the teacher and the students, and class presentations, epals, pictures and recommended relevant web resources ('A good web to go') were all converged in colourful words on the website. In addition, students were also required to $\log$ into the websites 'CityFamily' and 'forMOOsa' where out-ofcampus supportive class-based virtual English learning environments were constructed. In the CityFamily, for instance, the teacher required students to practice computer-mediated communication through the use of chatting and discussion functions, while in the forMOOsa the teacher encouraged students' creation of objects and English 'writing houses'.

Contents of the course

English was the main language used throughout class activities, which included English website information collection, topic-centred discussion, on-line communication, and email exchange. In autumn 2000, the course used four major tools-the World-wide web, Newsgroups, Chatrooms, and email to cultivate students' network accessibility and language expressions/utterances so that the course was 
given primarily in four segments. First, for the World-wide web section, Project A - self introduction and Project B - website recommendation were their assigned tasks. Second, in the Newsgroup section, the teacher asked students to subscribe to the newsgroups they were interested in and then used the CityFamily to post articles and questions and required students to either answer the questions or discuss the given topics in English. Third, in the Chat section, the students were allowed to freely 'e-talk' about whatever interested them in the chat room in CityFamily. Through the different presentation formats of online tutoring, online discussion, and online debate, they were given different objectives each time. Finally, in the email section, students learned the basic commands by using Outlook and basic ideas about email user interface design and the system setup and some key functions (POP setup, web-mail, filtering, and so on).

\section{Participants}

The participants in this study were 29 third-year high school students: 22 females and 7 male students plus the young male teacher. To take the elective course 'Internet and English', certain prerequisites were required. For instance, the students needed to have previously taken 'Introduction to Computer Science' and 'Applications of Computer Science', which were the first-year and second-year courses.

\section{Assessment}

For this course students were assessed as follows: $20 \%$ for class participation, $20 \%$ for homework exercises, $30 \%$ for the combined score on the 1 st and 2 nd midterm exams, and $30 \%$ for the final exam. Projects A and B were counted as the scores of the 1 st midterm. The quality as well as the quantity of each student's specific online utterances - their portfolio - was used as students' 2nd midterm scores. The Chat performance in the CityFamily was used for the final exam grades. The Final exam consisted of an article on the topic 'How do I perceive Internet and English'; students were instructed to talk about the current semester only and to include three parts: my impression of this class; what I have learned from this course and my suggestions.

\section{Methodology}

The study employed both qualitative and quantitative methods. The researcher used a multimethod approach to document and evaluate the process of integration of the Internet in the English learning settings, including the collection of their electronic data from chats, discussions, dialogues and email exchanges on the Internet, observations of their online classroom activities, formal and informal interviews with the instructor. A post-class questionnaire was administered to the participants at the end of this class. In addition, a student who had a special need for remedial instruction had actively interacted with the English teacher via email communication throughout most of semester. The student's email exchanges with the teacher were used as a case study.

\section{Data collection}

Data collected for the studies included authentic email messages, questionnaires, classroom observations, formal and informal interviews, and student logs. 
Descriptive statistical information was provided for cross-referencing. The study was conducted in a natural learning setting. None of the student subjects were aware of being observed and analysed during the data collection procedures.

\section{Duration of the study}

The study was conducted over two semesters: autumn/fall semester, from September 2000 to January 2001, and spring semester from February 2001 to June 2001. Because the students in the spring semester were not the same as those in the previous group due to dropouts and new participants, the results reported here are mainly based on the data for the first academic semester of the project.

\section{Basis of the data analysis}

Five research questions guided the study and the data presented here focuses primarily on the following three areas:

- overall results of the use of information communication technology in the class;

- students' English learning in terms of the use of information communication technology, including quantitative data, qualitative data and an individual case study analysis; and

- student perceptions of the use of IT in English learning based on analysis of the questionnaires.

The research, data collected and the data analysis of these themes are described in the following parts of this paper.

\section{Overall results of the use of ICT in the class}

The teacher used an open-ended question to solicit student overall responses to the use of information communication technology in the class. This question was, 'Do you think Internet and English can really improve your English? Tell me why.' Most students thought the Internet was an interesting and useful tool in their Internet and English class (Table 1).

Table 1. Data from the open-ended question

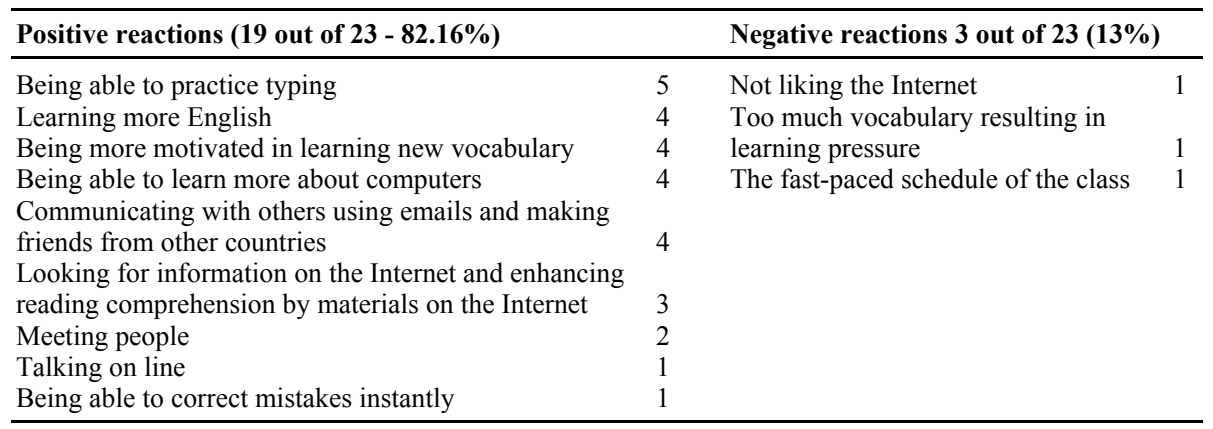

The 'Tell me why' self-report data were used for further analysis. The positive perception of Internet use could stem from two sources. First, due to the convenient access provided by the Internet, students were able to make foreign friends. Second, in the process of navigating the webpages, the chances of directly reading English and learning new vocabulary, sentence patterns, and grammatical patterns increased. Moreover, the immediacy of the online tutoring enabled the teacher to correct their mistakes quickly. The other advantages include the acquisition of relevant or 
interesting information on the Internet and an increase in computer skills, such as typing speed, using email, chatting online and surfing webpages.

On the negative side, the class schedule and lessons resulted in learning pressure. There were students who didn't have computers at home and the chances of getting on the Internet or practising typing decreased. Those students could only use class time and breaks during the school day to access the computers in the computer classroom. Access might be a major disadvantage.

Online discourse data analysis

The data for quantitative analysis were gathered from the Chat function in CityFamily, which generally meant participating in online tutoring and online debates. Also, the data from both the midterm exam and final exam in the first semester were collected for analysis. In online tutoring and online debate, not every student wrote down his or her responses. Although five students were completely silent, the other 24 students had at least one sentence (here one sentence means an utterance with 'a period' or 'a question mark' at the end) in the online chatting. However, in online debate, which discussed the interesting topic of 'having a girl friend or a boy friend', the volume of discourse obviously increased by an average of six sentences, and that was five times as many as the very first time, when they were required to talk about 'a good teacher'. Most students, who had already etalked the first time, were more likely to write more than the second time. As for the 2nd midterm exam and final exam, since the written records were used for students' grades, every student was mandated to express his or her opinions in order to gain points. Eventually the volume of the discourse resulted in an average of approximately 15 sentences in final exam. This was two and half times as many as in the midterm exam.

When addressing the reasons for the increase in students' discourse volume, the researcher found that students' gradual increasing familiarity with the computer commands and the digital environment contributed to the increased number of their expressions. Moreover, the topics for discussion which appeared to be interesting, controversial or abundant in readily available online information also resulted in an increase in the number of sentences.

Non-online discourse data analysis based on two projects

In addition to the online data, non-online data were collected from Project $A$ and Project B for analysis. For Project A, in order to encourage students to begin their English writing, the English teacher purposefully used 'self-introduction' as an introductory and familiar topic. Thus each student was asked to use English to introduce himself/herself. For Project B, each student had to browse the English resources on the Internet and then recommended some websites as their favourites and to give reasons for their recommendation. Consequently, the average number of sentences produced in Project A was eight, and this was about four times as many as the number produced for Project B. Further analysis of the in-depth data revealed that Project A was a self-introduction and there were several basic items that the students could always include in their written presentations, such as blood type, sign of Zodiac, and favourite sports. On the other hand, Project B asked students to recommend a web site that they found interesting. This topic was of wide scope and more challenging than Project A. Unlike Project A, Project B did not have a fixed 
writing format; some students only wrote several lines to fulfil the basic requirement, such as a website name and its URL. The nature of topics was another factor that influenced student motivation and willingness to write. These are the obvious differences between Project A and Project B in this study.

Table 2. Project A - Self introduction

\begin{tabular}{lrcc}
\hline Categories & Female (22) & Male (6) & Subtotal \\
\hline Name & 22 & 7 & 29 \\
Age & 11 & 5 & 16 \\
Sign of the Zodiac & 9 & 0 & 9 \\
Interests & 19 & 6 & 25 \\
Level of education & 5 & 1 & 6 \\
Blood type & 5 & 0 & 5 \\
Family members & 11 & 3 & 14 \\
Willing to make friends & 7 & 4 & 11 \\
Place of residence s & 4 & 5 & 9 \\
Birthday & 6 & 1 & 7 \\
Others & 12 & 3 & 15 \\
\hline
\end{tabular}

Table 3. Project B - Website recommendation

\begin{tabular}{lcccc}
\hline Categories & Female & Male & Subtotal & Total \\
\hline Transportation & 1 & 0 & 1 & \\
Recreation & 12 & 1 & 13 & \\
Sports & 1 & 3 & 4 & \\
Medicine & 1 & 0 & 1 & \\
Education/Information & 6 & 3 & 9 & \\
Others & 1 & 0 & 1 & 29
\end{tabular}

From Table 2, It can be seen that every student mentioned his or her name (29 students), age (25), interests (16) and family members (14). It could be concluded that the participants wrote their selfintroductions in a fixed mode and that made the introduction less appealing compared to other content presented in the other projects or topics.

In Project B (see Table 3), the most popular websites recommended by most of the students were related to recreation. The recreation category included movies, singers, and magazines. While recreational websites were students' first favourites, some other students recommended websites that could provide them with new information about computers, news updates, or even drums. There were a few students who were intrigued by sports (i.e. basketball in the present case) and who recommended basketball websites.

Table 4. Average number of written sentences

\begin{tabular}{lrcrccc}
\hline & \multicolumn{2}{c}{ Female (22) } & \multicolumn{2}{c}{ Male (7) } & \multicolumn{2}{c}{ Total (29) } \\
& Sum & Average & Sum & Average & Sum & Average \\
\hline Project A & 176 & 8.00 & 54 & 7.71 & 230 & 7.93 \\
Project B & 93 & 4.22 & 36 & 5.14 & 129 & 4.44 \\
& & & & & &
\end{tabular}

The data presented in Table 4 reveal that gender was not a factor influencing the volume of student written sentences in this study. Contradictory to stereotypes, female and male students in this study wrote a similar volume of sentences in both Project A and Project B.

\section{Students' English learning/improvement in terms of the use of the ICT}

The teacher in this 'Internet and English' class intended primarily to incorporate the use of the Internet to motivate students' English communication because, according to the analysis of learners' characteristics, he realised that those students in general were passive and intimidated by English writing/composition but that the students indicated their interest in using Internet tools for a practical purpose. Thus, his major concern in his course design was how to integrate the Internet to facilitate students' English e-writing and communication skills for a practical purpose or to enhance students' English learning in association with web literacy. In the follow up interviews, the teacher reported that he was neither involved in correcting students' 
grammatical constructions nor were students asked to help comment on their fellow students' sentence construction. The teacher expected that students would become more active English e-talk users and, at the same time, they would gradually make progress in their use of English expressions by paying attention to peers' or the teachers' writings on the Internet. Thus, the discourse data generated in this natural learning setting were valuable in the Chinese/Taiwanese specific language-speaking context. To investigate whether or not the strategy employed by the teacher was effective, in-depth data were collected from a case study and the result is analysed below.

A case study using email for remedial instruction

Hsiao-Hua (pseudonym, his English name was Peter) was 16-years-old. His English level was about average, ranking 15th in this class of 29 students. He was taking 'Internet and English' with high motivation because he had a special interest in playing musical instruments and in using computer networks; his speciality was webpage design and construction. He enjoyed helping other students and maintained a good interpersonal relationship. However, the low social economic status of his family required Peter to have a part-time job to support himself so that he seldom had much time to review the course materials learned in class. This situation put him at a disadvantage.

In order to accommodate Hsiao-Hua's special needs and to assist him in his learning, the teacher, offered him a special email remedial instruction program based on both the course materials and on his special skills in webpage design and construction. The teacher asked Hsiao-Hua to construct a class homepage to support the course under the condition that he was required to use English to communicate with the teacher for further instructions via email throughout the class home page construction process. If Hsiao-Hua could successfully complete the project, he could win extra bonus points. Basically it was a task-oriented English tutoring project. Hsiao-Hua would use email and English in an authentic and less-pressured learning environment where he could communicate with the teacher at his convenience from any place. In a subsequent interview, the teacher said that in order to keep the dialogue going, he assumed that Hsiao-Hua would be pushed to look up new words in the dictionary and to check the grammar and sentence patterns. It was expected that this indirect learning could enhance Hsiao-Hua's reading and writing abilities.

\section{Data analysis of the email remedial instruction program}

During the class homepage construction process, the teacher in total received 72 messages from Hsiao-Hua in 12-weeks of correspondence, from October to December 2000. On average, Hsiao-Hua sent six email messages per week (see Fig. 1).

Figure 1 shows that the distribution of the email messages declined as the weeks passed. It was observed that Hsiao-Hua sent and received many messages at the beginning of the remedial tutoring. In the first week, he sent over 20 messages to the teacher. With the new mission and novelty of the technology, he showed high interest in sending and receiving email for the very first time. However, his enthusiasm declined gradually. Particularly, in the eighth and ninth weeks, the number of the email messages fell to zero. However, two peaks appeared in the 5th and the 10th weeks that corresponded with the midterm examinations. Noticeably, 
Hsiao-Hua took advantage of the email channel to ask questions regarding examinations outside of class hours. This may be the reason why the amount of email increased again.

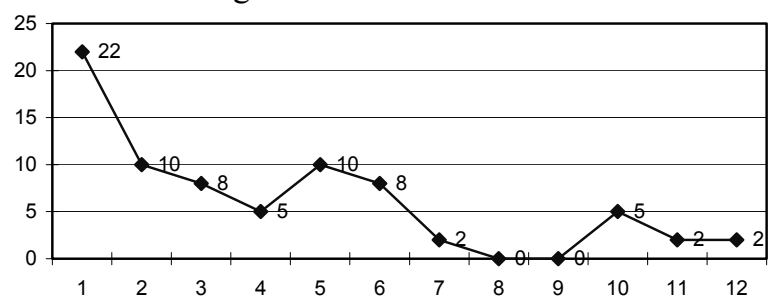

Fig. 1. Distribution of Hsiao-Hua's email messages each week
The number of messages went up around December 2000 because the construction of the class homepage was almost completed. The teacher needed to evaluate how Hsiao-Hua did his assignment and

the teacher also needed to add more related data to the web site. After January 2001, there was basically no email exchange since Hsiao-Hua had already completed the task of web site construction. Also, the novelty may have gradually disappeared as he became accustomed to using this kind of communication channel.

In the follow-up interview, the teacher confessed that the decline of Hsiao-Hua's email messages discouraged him somewhat. However, the teacher felt inspired again when he noticed that Hsiao-Hua later became a more active participant in on-line talk. He participated more frequently and presented more utterances than the other students of his level.

Analysis of a student's English writing through email communication

Although Hsiao-Hua still made grammatical errors, the teacher said of Hsiao-Hua's discussion in this talk, 'overall, his on-line talk was good and impressive to me'. He said, 'typos were a very common phenomenon on the Internet communication and were not a major concern in this course design'. The teacher expected that those students would be able to use the Internet for synchronous or asynchronous communication in an authentic setting for practical purposes in the future. 'When I designed this course, I first cared more about whether or not my students could use the Internet for e-talk fluently in English'. 'I hoped that they could dialogue with each other and say what they wanted to say'. 'In an on-line communication mode in particular, I value more of the content of their expressions than grammatical structures and accuracy'. In comparing Hsiao-Hua's dialogue with other students, obviously his e-talk was richer and longer. It shows that Hsiao-Hua had reached a certain stage of fluency and could express his ideas through the Internet.

\section{Student perceptions of the use of ICT in English learning}

In order to understand students' perception of learning English by using the Internet and the impact of the Internet on English learning as well, a questionnaire was administered to the students shortly before the end of the first semester in order to collect their demographic information and their responses to the use of the Internet in this English class. The questionnaire was composed of three parts: personal data; experience in using a network computer; and ten 5-point-Likert-scale questions. A general question was given at the beginning of the questionnaire and 10 more corresponding statements followed with choices. A total of 26 questionnaires out of 29 were collected and used for analysis. The statistical results of this questionnaire are presented below (Table 5). 
According to the data collected from the questionnaire, the above 10 statements received overwhelmingly positive responses from the students. Noticeably the top ranked were: statement 1 (94.2\%); statements 3, 4 \& 8 (92.4\%); and statements 6 \& $9(88.5 \%)$. Feeling less pressured, making mistakes anonymously, learning good English sentences from other people, making foreign key/pen pals, finding interesting information on the Internet and practising English often were perceived to be the major benefits to their English learning through the use of the Information communication technology. On the other hand, the lowest rating was $63.8 \%$ (statement 7). In other words, up to $35 \%$ of students did not think that online English chatting could improve their response time.

Table 5. Results of questionnaire (Rank by percentage)

What do you think might be the reasons that the Internet could facilitate English learning?

(1-Totally Disagree; 2 -Strongly Disagree; 3-Agree; 4 - Strongly Agree; and 5--Totally Agree)

\begin{tabular}{|c|c|c|c|c|c|}
\hline Statements & 2 & 3 & 4 & 5 & Rank \\
\hline The teacher interacted with students on the & $3.8 \%$ & $57.7 \%$ & $15.4 \%$ & $23.1 \%$ & 1 \\
\hline Internet so that I feel less pressured in class. & $3.8 \%$ & $94.2 \%$ & & & \\
\hline $\begin{array}{l}\text { 2. I can learn new vocabulary, sentence patterns, } \\
\text { and grammar on the Internet. }\end{array}$ & $\begin{array}{ll}0 & 19.2 \% \\
\mathbf{1 9 . 2 \%} & \end{array}$ & $\begin{array}{l}57.7 \% \\
\mathbf{8 1 . 8 \%}\end{array}$ & $15.4 \%$ & $7.7 \%$ & 8 \\
\hline $\begin{array}{l}\text { 3. Anonymous communication makes me less afraid } \\
\text { of making mistakes in English chatting. }\end{array}$ & $\begin{array}{c}3.8 \% 3.8 \% \\
7.6 \%\end{array}$ & $\begin{array}{l}42.3 \% \\
\mathbf{9 2 . 4 \%}\end{array}$ & $15.4 \%$ & $34.6 \%$ & 2 \\
\hline 4. I could learn good English sentences from others. & $\begin{array}{c}3.8 \% \quad 3.8 \% \\
7.6 \%\end{array}$ & $\begin{array}{l}30.8 \% \\
\mathbf{9 2 . 4 \%}\end{array}$ & $38.5 \%$ & $23.1 \%$ & 2 \\
\hline $\begin{array}{l}\text { 5. I don't need to speak English in front of my } \\
\text { classmates. Instead, typing in front of the } \\
\text { computer screen reduces my stress. }\end{array}$ & $\begin{array}{c}7.7 \% \quad 26.9 \% \\
\mathbf{3 4 . 6 \%}\end{array}$ & $\begin{array}{l}26.9 \% \\
\mathbf{6 5 . 4} \%\end{array}$ & $34.6 \%$ & $3.8 \%$ & 9 \\
\hline $\begin{array}{l}\text { 6. Learning English won't be that boring since I } \\
\text { could find some intriguing English information } \\
\text { on the Internet quickly }\end{array}$ & $\begin{array}{c}3.8 \% \quad 7.7 \% \\
\mathbf{1 1 . 5 \%}\end{array}$ & $\begin{array}{l}38.5 \% \\
\mathbf{8 8 . 5} \%\end{array}$ & $15.4 \%$ & $34.6 \%$ & 5 \\
\hline $\begin{array}{l}\text { 7. I could improve my English response speed since } \\
\text { online chatting in English requires instantly } \\
\text { answering in English. }\end{array}$ & $\begin{array}{c}7.7 \% \quad 26.9 \% \\
\mathbf{3 4 . 6 \%}\end{array}$ & $\begin{array}{l}30.8 \% \\
\mathbf{6 3 . 8 \%}\end{array}$ & $30.8 \%$ & $3.8 \%$ & 10 \\
\hline $\begin{array}{l}\text { 8. I could make key/pen pals in foreign countries } \\
\text { and practice English writing. }\end{array}$ & $\begin{array}{c}3.8 \% \quad 3.8 \% \\
7.6 \%\end{array}$ & $\begin{array}{l}23.1 \% \\
\mathbf{9 2 . 4 \%}\end{array}$ & $30.8 \%$ & $38.5 \%$ & 2 \\
\hline $\begin{array}{l}\text { 9. I could often practice English since English is } \\
\text { the common language on the Internet. }\end{array}$ & $\begin{array}{l}0 \quad 11.5 \% \\
\mathbf{1 1 . 5 \%}\end{array}$ & $\begin{array}{l}26.9 \% \\
\mathbf{8 8 . 5 \%}\end{array}$ & $38.5 \%$ & $23.1 \%$ & 5 \\
\hline $\begin{array}{l}\text { 10. I could freely practice English because I could } \\
\text { build up my little virtual world on the } \\
\text { computer screen. }\end{array}$ & $\begin{array}{c}3.8 \% \quad 11.5 \% \\
\mathbf{1 5 . 3 \%}\end{array}$ & $\begin{array}{l}34.6 \% \\
84.7 \%\end{array}$ & $26.9 \%$ & $23.1 \%$ & 7 \\
\hline
\end{tabular}

However, the total points that each question received, changes the result slightly. The following table (Table 6) lists the ranking of the total sum for each question.

From the statistical results of the questionnaire reported above, it is clear that statement 8. 'I could make key/pen pals in foreign countries and practice English writing' was the statement that students perceived to be the most beneficial advantage of using the Internet in English learning. The result indicates that for high school students, the establishment of social and interpersonal relationships by making key/pen pals from other countries is an inspiring way to enhance their motivation to improve their writing in English. This point explains why students might be more willing to take advantage of the powerful functions of the Internet because it empowers them to make friends by transcending the limitations of time and geography to facilitate English learning. In addition, meeting other people from other cultures on the Internet directly increases the chance of practising English, as indicated in the second highest ranking statements 4 and 9 . As a matter of fact, three statements - 3, $4 \& 9$ - are tied for rank 2 . Obviously, one of the second top 
reasons is statement 3. 'Anonymous communication makes me less afraid of making mistakes in English chatting.' Anonymity, also one of the Internet's unique characteristics, can help reduce students' ego boundaries and thus enable them to communicate freely with less concern with making mistakes. This point puts emphasis on the rationale: 'fluency first, grammatical accuracy second' as promoted in the communicative approach (Hymes, 1974) or intercultural communicative approach (Belisle, 1996). Taiwanese students are generally shy and afraid of expressing their own ideas or opinions before the public. They feel less confident particularly in speaking English publicly and are afraid of making mistakes in front of other people. In online communication one doesn't need to immediately reveal his/her true identity and thus stress may be reduced. The volume of student English output in the class reported earlier could support this point. As for the third and fourth reasons, students recognise the positive impact of the Internet on English language learning and acquisition.

Table 6. Results of questionnaire (Rank by total sum)

\begin{tabular}{|c|c|c|}
\hline \multicolumn{2}{|r|}{ Rank The reasons that the Internet could facilitate English learning } & Total points \\
\hline 1 & 8. I could make key/pen pals in foreign countries and practice English writing. & 103 \\
\hline 2 & 3. Anonymous communication makes me less afraid of making mistakes in English chatting. & g. 97 \\
\hline & & 97 \\
\hline & 9. I could often practice English since English is the common language on the Internet. & 97 \\
\hline 5 & $\begin{array}{l}\text { 6. Learning English won't be that boring since I could find some intriguing English } \\
\text { information on the Internet quickly. }\end{array}$ & 96 \\
\hline 6 & 1. The teacher interacted with students on the Internet so that I feel less pressured in class. & 93 \\
\hline 7 & $\begin{array}{l}\text { 10. I could freely practice English because I could build up my little virtual world on the } \\
\text { computer screen. }\end{array}$ & 92 \\
\hline 8 & 2. I can learn new vocabulary, sentence patterns, and grammar on the Internet. & 81 \\
\hline 9 & $\begin{array}{l}\text { 5. I don't need to speak English in front of my classmates. Instead, typing in front of the } \\
\text { computer screen reduces my stress. }\end{array}$ & 78 \\
\hline 10 & $\begin{array}{l}\text { 7. I could improve my English response speed since online chatting in English requires } \\
\text { instantly answering in English. }\end{array}$ & 77 \\
\hline
\end{tabular}

\section{Conclusion and discussion}

The results of this study reveal that most students perceived that the Internet was an interesting and useful tool in their Internet and English class. The use of information communication technology in an EFL class could motivate student learning and provide students with a less stressful environment to express their opinions and thoughts freely on the Internet thus students transformed learning from a traditional passive experience to one of discovery, exploration, and excitement in a less stressful setting. the result supports other studies which say that the Internet provides students with a less threatening means to communicate so that the use of the Internet increased engagement, confidence and responsibility (Chun, 1994; Beauvois, 1995; Skinner \& Austin, 1999). However, the Internet alone could not improve student English writing in terms of linguistic proficiency and grammatical accuracy, even though the communication messages were archived and saved. Most students in this study welcomed computers as a powerful tool to be integrated into English learning.

The students identified nine benefits of using the Internet in class but three negative reasons were also given. Computer access was also a concern of those students who did not have computers at home. Lack of home computer access would put those students at a disadvantage because they could only use class time and class breaks during the school day to access the computers in the computer lab. 
Additionally, this study reveals that gender was not a factor influencing the volume of student writing. Contradictory to stereotypes, female and male students in this study wrote a similar number of sentences.

The case study supports other studies which say that learning to use network computers provides a strong intrinsic motivation for learning English, and students could be empowered by the capacities of the technology and become better problem solvers and better communicators (Belisle, 1996; Muehleisen, 1997; Al-Kahtani, 1999). This point could be proved in Hsiao-Hua's self-report data. He revealed that he was very excited about the novice use of email for English communication and homepage production for the following reasons: Firstly, for the first time he was mandated to use email for English communication in such a practical situation. Hsiao-Hua regarded communicating with his English teacher in particular as an honor. Before this assignment, he was not so comfortable with English sentence writing, let alone English composition. Hsiao-Hua viewed English e-writing as a little easier than writing an English composition. Secondly, home page construction was his favourite activity and making a class webpage was something he knew he could do well. He was very comfortable with the assigned task and his contribution to the construction of the class homepage could help him win respect and reputation among his fellow students. Lastly, his completion of the class home page could gain him more bonus points to compensate for the limited time he spent on course material review due to his need to have part-time job to support himself.

\section{Implications and recommendations}

The results of this study prove that indirect hints did not improve grammatical accuracy. The study leaves a question for future study: if the teacher constantly corrected students' errors, how well could those students improve their language proficiency and grammatical errors in the long run? More studies on pedagogical strategies, how, when and how frequently to correct student grammar through English writing practice on the Internet should be followed. A few students remained silent in synchronous e-talk. The causes of their silence were not further identified due to the limited data available in this regard. Whether or not these students had difficulties resulting from their limited English proficiency or their slow typing speed (Chien \& Liou, 2002) deserves further investigation.

It is noted that according to the questionnaire, anonymity and the less-pressured environment were the two major factors to foster students' online writing. However, whether or not those two factors also fostered the large amount of grammatical errors and typos in students' utterances on the Internet deserves further exploration.

The teacher voiced a lot of concerns about classroom management in the virtual classroom setting. In addition, with this new method the teacher needed to prepare up-to-date digitised teaching materials and he had to respond to student synchronous and asynchronous questions via email correspondence in a timely way. In general, preparing a network session plus taking care of the after-class online activities demanded up to three to four times the class time that a traditional session required. Although the incorporation of ICT in ESL learning and teaching is the trend nowadays, schools should not just jump on the ICT wagon. Rather it is highly suggested that the policies concerning curriculum design, pedagogy and the whole school supporting systems in the peer-teacher community and logistic services should be updated and reinforced. 
The integration of the Internet could provide an exciting and significant alternative teaching and learning approach to enhance language acquisition, but the Internet itself is not necessarily a substitute for ESL education. Although communication is at the heart of second language learning, the most fundamental cornerstones of ESL learning are reading, writing, speaking and listening abilities. Depending on the goals of an ESL course, an English teacher must adopt appropriate pedagogical strategies and activities to meet the desired objective. It is suggested that more related or comparison studies regarding the adaptive strategies of combining English acquisition and Internet usage to improve reading, writing, speaking and listening abilities in various schooling contexts, pedagogy, new kinds of learning activities, accessibility of computers, and locating decent topics to motivate students' learning interest should be encouraged for further investigation in the future.

\section{Limitations of this study}

In consideration of privacy, the researcher could not collect some desired data such as emailed messages, and that fact indeed affected the research results. The study was by nature basically a qualitative approach. The in-depth descriptive data reflect the integration of the Internet in a specific English learning context in Taiwan. Therefore, the results of this study cannot necessarily be generalised to other situations.

\section{Acknowledgements}

This research project was supported by National Science Council (NSC89-2511-S007-013), Taiwan, R.O.C. The author wishes to express her sincere gratitude to the students and the teacher involved in the study. The author also wishes to thank the editor, Professor Robert Lewis and anonymous reviewers for insightful comments and helpful suggestions for further development of this paper. An early draft of this paper was presented at Ed-Media 2002 held in June 2002 at Denver, Colorado.

\section{References}

Al-Kahtani, S. (1999) Teaching ESL reading using computers. The Internet TESL Journal, 5, 11. (http://www.aitech.ac.jp/ iteslj/Techniques/AlKahtani-ComputerReading/)

Beauvois, M.H. (1992) Computer-assisted classroom discussion in the foreign language classroom: Conversation in slow motion. Foreign Language Annals, 25, 5, 455-464.

Beauvois, M.H. (1995) E-talk attitudes and motivation in computer-assisted classroom discussion. Computer and the Humanities, 28, 177-190.

Belisle, R. (1996) Email activities in the ESL writing class. The Internet TESL Journal, 2, 12. (http://www.aitech.ac.jp/ iteslj/Articles/Belisle-Email.html)

Chien, I.C. \& Liou, H.C. (2002) A study of an on-line multi-user English learning environment for senior high school students. In Proceedings of Taiwan Area Network Conference, pp. 359-362. National Tsing Hua Univesity, Hsinchu, Taiwan.

Chun, D. (1994) Using computer networking to facilitate the acquisition of interactive competence. System, 22, 17-31.

Donaldson, R.P. \& Kotter, M. (1999) Language learning in cyberspace: Teleporting the classroom into the target culture. CALICO, 16, 4, 531-543. 
Ehrman, M.E. (1993) Ego boundaries revisited: Toward a model of personality and learning. In Georgetown University Round Table on Languages and Linguistics 1993. (ed. J.E. Alatis) pp. 330-362. Georgetown University Press, Washington, DC.

Gardner, R.C. \& Lambert, W.E. (1972) Attitudes and Motivation in Second Language Learning. Newbury House Publishers, Rowley, MA.

Guiora, A.Z., Acton, W.R., Erard, R. \& Strickland, F.W. (1980) The effects of benzodiazepine (valium) on permeability of ego boundaries. Language Learning, $\mathbf{3 0}$, 301-363.

Guiora, A.Z., Beit-Hallami, B., Brannon, R.C., Full, C.Y. \& Scovel, T. (1972) The effects of experimentally induced changes in ego states on pronunciation ability in second language: An exploratory study. Comprehensive Psychiatry 13, 5, 421-428.

Heyde, A. (1979) The Relationship between Self-esteem and the Oral Production of a Second Language. Unpublished doctoral Dissertation, University of Michigan.

Hymes, D. (1974) Foundations in Sociolinguistics. University of Pennsylvania Press, Philadelphia.

Kelm, O.R. (1992) The use of synchronous computer networks in second language instruction: a preliminary report. Foreign Language Annals, 25, 441-545.

Kern, R. \& Warschauer, M. (2000) Theory and practice of network-based language teaching. In Network-Based Language Teaching: Concepts and Practice (eds. M. Warschauer \& R. Kern) pp. 1-19. Cambridge University Press, New York.

Lee, K.W. (2000) Energizing the ESL/EFL classroom through Internet activities. The Internet TESL Journal, 6, 4. (http://www.aitech.ac.jp/ iteslj/Articles/Lee-InternetActivities.html).

Liao, C.C. (1999) Emailing to improve EFL learners' reading and writing abilities: Taiwan experience. The Internet TESL Journal, $\mathbf{5}, 3$. (http://www.aitech.ac.jp/ iteslj/Articles/Liao-Emailing.html).

Liou, H.C. (2000) Conceptualization and implementation of an English learning Web site which bridges TEFL theories and practices. In Proceedings of the 4th International Conference on Multimedia Language Education. (http://teens.cs.nthu.edu.tw/ excel6/paper/Rocmelia00n.doc).

Muehleisen, V. (1997) Projects using the Internet in college English classes. The Internet TESL Journal, 3, 6. (http://www.aitech.ac.jp/ iteslj/Lessons/Muehleisen-Projects.html).

Negretti, R. (1999) Web-based activities and SLA: a conversation and analysis research approach. Language Learning and Technology, 3, 1, 75-87.

Pike, K. (1967) Language in Relation to a Unified Theory of the Structure of Human Behavior. Mouton Publishers, The Hague.

Shetzer, H. \& Warschauer, M. (2000) An electronic literacy approach to network-based language teaching. In Network-Based Language Teaching: Concepts and Practice (eds. M. Warschauer \& R. Kern) pp. 171-185. Cambridge University Press, New York.

Skinner, B. \& Austin, R. (1999) Computer conferencing: Does it motivate EFL students? ELT Journal, 53, 270-280.

Vallance, M. (1998) The design and use of an Internet resource for business English learners. ELT Journal, 52, 1, 38-42.

Warschauer, M. (1997) Compute-mediated collaborative learning: Theory and practice. Modern Language Journal, 81, 470-481. (http://www.gse.uci.edu/markw/cmcl.html).

Warschauer, M. (2000) Online learning in second language classrooms: An ethnographic study. In Network-Based Language Teaching: Concepts and Practice (eds. M. Warschauer \& R. Kern) pp. 41-58. Cambridge University Press, New York.

Watkins, D., Biggs, J. \& Regmi, M. (1991) Does confidence in the language of instruction influence a student's approach to learning? Instructional Science, 20, 331-339.

Yang, S.C. (2001) Integrating Computer-mediated tools into the language curriculum. Journal of Computer Assisted Learning, 17, 85-93. 
Copyright of Journal of Computer Assisted Learning is the property of Blackwell Publishing Limited and its content may not be copied or emailed to multiple sites or posted to a listserv without the copyright holder's express written permission. However, users may print, download, or email articles for individual use. 